Tema je ovog broja Društvenih istraživanja Suvremeni izazovi psihologije rada i organizacijske psihologije. Pod istim je naslovom potkraj 2013. godine u Zagrebu održana 21. godišnja konferencija hrvatskih psihologa. Neki od pozvanih predavača i autora koji su svojim priopćenjima sudjelovali na toj konferenciji rezultate svojih recentnih istraživanja objavljuju u ovom posebnom broju.

Rad Šverka i Galića pruža teorijski utemeljenu operacionalizaciju kvalitete radnoga života, koja uključuje percepciju ekonomske sigurnosti, socijalnih odnosa na poslu, smislenosti rada te samostalnosti u radu i sudjelovanja u donošenju odluka. Na velikom uzorku autori uspoređuju kvalitetu radnoga života u Hrvatskoj s onom u dvije skupine zemalja članica EU-a. Rezultati potvrđuju ne samo razlike između istočnih i zapadnih članica Unije nego i pokazuju da kvaliteta radnoga života odražava razlike u društvenom uređenju uključenih zemalja.

De Cuyper, De Witte, Sverke, Hellgren i Näswall istražuju u Belgiji odnos percipirane nesigurnosti posla i članstva u sindikatima među zaposlenicima s ugovorom na određeno i neodređeno vrijeme. Rezultati pokazuju da je osjećaj nesigurnosti posla pozitiono povezan s članstvom u sindikatu među privremeno zaposlenima, ali ne $i$ kod stalnih radnika. Kako je traženje socijalne zaštite važan motiv sindikalnog organiziranja, autori zaključuju da su nalazi njihova istraživanja izazov sindikatima u procesima regrutiranja, organiziranja i zastupanja privremenih radnika.

Autorice Maslić Seršić i Tomas konstruiraju upitnik kojim na hrvatskom uzorku preispituju model zapošljivosti. Njihov upitnik dispozicijske zapošljivosti uključuje procjene radne samoefikasnosti, proaktionosti, angažmana i socijalnoga kapitala. Autorice validiraju upitnik u odnosu na relevantne mjere sličnih konstrukata i neke ključne kriterijske varijable uspjeha u karijeri uz kontrolu relevantnih demografskih obilježja i karakteristika zaposlenja.

Jakopec i Sušanj provjeravaju interakcijske efekte doživljaja pravednosti rukovoditelja $i$ organizacije na rukovoditelju i organizaciji usmjerene ishode. Autori potvrduju pretpostavku da su pozitioni učinci na svim mjerenim ishodima najizraženiji u situacijama kada zaposlenici oba izvora istodobno doživljavaju pravednim. Međutim, neusklađenost stupnja $i$ smjera pravednosti različitih izvora odražavaju se različito s obzirom na promatrane kriterijske varijable i dimenzije pravednosti.

Nije slučajno što teme uključenih radova zapravo ulaze u šire područje radne motivacije. Naime, današnji odnos prema radu i karijera zaposlenih uvelike je obilježena gospodarskom krizom. Ovo se posebno vidi u sve većoj nezaposlenosti, sve češćem sklapanju ugovora o radu na određeno vrijeme i liberalizaciji ne samo tržišta rada nego i odnosa organizacija prema zaposlenicima. Upravo stoga istraživanja kvalitete radnoga života, osjećaja nesigurnosti zaposlenja, procjene osobne zapošljivosti $i$ doživljaja pravednosti u 
radnom kontekstu zaista predstavljaju suvremene izazove psihologije rada i organizacijske psihologije. Zato sam uvjeren da će radovi objavljeni u ovom posebnom broju Društvenih istraživanja biti zanimljivi ne samo istraživačima nego i praktičarima koji se bave upravljanjem i razvojem ljudskih potencijala.

\section{The Theme}

This issue of Društvena istraživanja is dedicated to Contemporary Challenges in Work and Organisational Psychology, the topic of the 21st Annual Conference of Croatian Psychologists held in Zagreb in late 2013; some of the conference's invited speakers and paper authors share the results of their recent research in this special issue.

In their paper, Šverko and Galić offer a theoretically-founded operationalisation of quality of working life, incorporating the perception of economic security, social relations at work, meaningfulness of work, autonomy, and participation in decision making. A large sample is used to compare the quality of working life in Croatia to the quality of working life in two groups of EU countries. In addition to confirming the differences between East and West European members, the results indicate that the quality of working life mirrors the differences in the participating countries' social systems.

De Cuyper, De Witte, Sverke, Hellgren and Näswall look at the relationship between perceived job insecurity and union membership of Belgian employees on temporary and permanent contracts. The results show that the perception of job insecurity correlates positively with union membership among temporary workers, but not among permanent employees. As seeking social protection is an important motive for unionisation, the authors conclude that their research results present a challenge to unions in recruiting, organising and representing temporary workers.

Maslić Seršić and Tomas have constructed a questionnaire which they use to reassess the employability model on a Croatian sample. Their dispositional employability questionnaire includes evaluations of work self-efficacy, work proactivity, work engagement and social capital. The authors validate the questionnaire with reference to relevant measures of similar constructs, as well as some key criterion variables of career success, controlling for relevant demographic and work-related variables.

Jakopec and Sušanj examine interaction effects of the perception of supervisory and organisational justice on supervisor-and organisation-oriented outcomes. The authors confirm the hypothesis that positive effects are most pronounced in all the outcomes measured when employees simultaneously perceive both sources as fair. However, the discrepancy between the degree and direction of justice of different sources is reflected variously in relation to the criterion variables and justice dimensions examined.

It is not coincidental that these papers delve into topics that really belong to a wider field of work motivation. Employees' attitudes toward work and career are at present greatly 
affected by the economic crisis. This is particularly evident from mounting unemployment, the ever-increasing frequency of temporary employment, and the liberalisation not only of the labour market, but also of organisations' treatment of employees. It is precisely for this reason that research on quality of working life, job insecurity perception, employability self-evaluation and perceived justice in a work context is really a contemporary challenge to work and organisational psychology. I am therefore convinced that the papers published in this special issue of Društvena istraživanja will be of interest not only to researchers, but also to practitioners in the field of human resources management and development.

Zoran Sušanj 